\title{
ROAD DESIGN ON LOW BEARING CAPACITY SOILS
}

\author{
ENDIJS VIRSIS*, AINARS PAEGLITIS, ATIS ZARINS \\ Dept of Roads and Bridges, Faculty of Civil Engineering, \\ Riga Technical University, Riga, Latvia
}

Received 2 March 2020; accepted 8 June 2020

\begin{abstract}
Soil with weak bearing capacity, like peat and organic grounds, is widespread in Latvia. During the geotechnical investigation for road reconstruction projects, in many cases the discovered soils with low physicalmechanical properties are located below the existing road structure. It is a challenge for a road design engineer to find a way how to ensure road loadbearing capacity and prevent the occurrence of various deformations. Various methods and technologies for ground structure reinforcement and stabilization are being developed worldwide. During design of road structures, it is important to analyse the geotechnical situation and to identify the main reasons why deformations could occur in the ground layers under the road structure. Each of the developed technologies for weak and unstable soil reinforcement, stabilization is designed to solve a specific problem. Inaccurately and carelessly identifying the causes of problems, road deformations can affect the performance of the recently designed road and even make the existing problem worse. The aim of this paper is to show the soil strengthening methods used in Latvia and to analyse the benefits and disadvantages of these methods.
\end{abstract}

Keywords: construction, geotechnical design solutions, low bearing soil, peat, roads, soil reinforcement.

\footnotetext{
* Corresponding author. E-mail: endijs.virsis@inbox.lv

Endijs VIRSIS (ORCID ID 0000-0001-6565-7239)

Ainars PAEGLITIS (ORCID ID 0000-0002-1916-7682)

Atis ZARINS (ORCID ID 0000-0003-1731-2206)

Copyright (c) 2020 The Author(s). Published by RTU Press

This is an Open Access article distributed under the terms of the Creative Commons Attribution License (http://creativecommons.org/licenses/by/4.0/), which permits unrestricted use, distribution, and reproduction in any medium, provided the original author and source are credited.
} 


\section{Introduction}

Latvia is in a tectonically stable, geologically ancient area to the northwest of the Eastern European craton, at the same time to the west of the Eurasian lithosphere plate. Three basic elements can be distinguished in Latvia's geological structure: 1) the Proterozoic bedrock, which forms a solid, crystalline bedrock beneath the sedimentary rocks; 2) layered sedimentary rocks; 3) their quartering cover, which was largely formed by icing (Stinkulis, 2019).

The temperate climate of Latvia with more precipitation than evaporation, as well as the gentle wavy terrain and clayey, poorly permeable sediments in the bog valleys are favourable conditions for the formation and development of bogs. Nowadays, bog complexes in Latvia are complex dynamic systems that have been established and developed for thousands of years and are still growing intensively horizontally and vertically, significantly influencing landscape dynamics. Bogs occupy more than $10 \%$ of the territory of Latvia, where at least $30 \mathrm{~cm}$ thick peat layer accumulated during the last 11700 years. They are distributed throughout the country, but their location in the natural areas varies. The largest swamps are found in Eastern Latvia, Central Latvia and Seaside Lowlands, where the largest swamps are located - Teiču swamp (14 074 ha), Cenas moorland (10 600 ha) and Great Kemeri moorland (5000 ha).

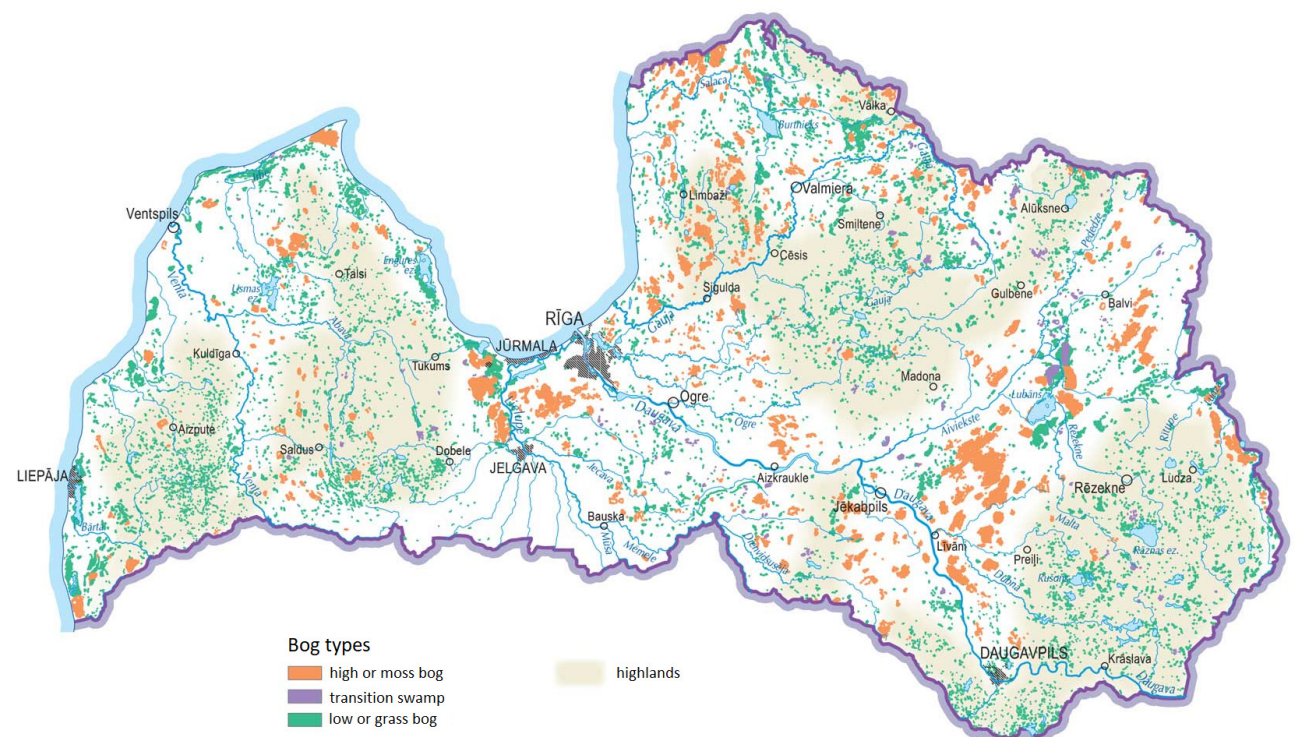

Figure 1. Bog distribution in the territory of Latvia 
Bogs in Latvia have developed in negative relief forms of the Earth's surface, mainly due to the action of the last glacial ice and its melting waters (see Figure 1). The exception is the coastal areas where the formation of the terrain was significantly influenced by the geological processes caused by the development stages of the Baltic Sea. The marshes in the territory of Latvia were formed by overland swamping or overgrowing of shallow water bodies, and their formation was significantly influenced by the terrain (Kalnina, 2019).

Road construction over soil with weak bearing capacity presents great challenges to the intending road builder not only in the landscapes and terrain that have to be crossed but also in the management of the engineering properties of soil, high water content, high compressibility and low strength. The road engineer must overcome these engineering obstacles and considerations of low bearing capacity and excessive settlement in order to be able to construct safe, stable and serviceable road embankments. Soil problems with poor bearing capacity are encountered worldwide, which has led to the development of various methods and technologies for ground structure reinforcement and stabilization over the years. In order to be able to offer the most economical and rational reinforcement solution during the design process, it is necessary to precisely identify the main risks that could affect the road capacity (Guyer, 2018).

\section{Objectives}

The aim of this publication is to evaluate technologies and methods for road design on low bearing capacity soil, to evaluate the advantages and disadvantages of each method and to look at Latvia's experience in geotechnical design of roads.

Bearing capacity is the strength of soil to support the loads applied to the ground. The bearing capacity of soil structure system is the maximum average contact pressure between the foundation and the soil, which should not produce shear failure or excessive settlement in the soil.

\section{Road construction design on low bearing capacity soils}

There are several techniques to improve the bearing capacity of the soil and two major construction strategies, including low bearing 
capacity soil removal and left in place. Removal means doing away with the low bearing capacity soil prior to the construction - soil excavation, replacement and displacement. Weak soil left in place entails all the constructions that are undertaken directly on this soil in order to avoid bulk earthworks and the methods are consolidation, ground improvement to reduce deformation, load modification, stabilization and piling methods.

Construction over low bearing capacity soil can essentially be subdivided into five broad classifications:

- rerouting;

- excavation of weak soil and replacement;

- replacement;

- displacement;

- soil left in place.

Excavation can be rated as the safest and most popular option of new or existing road structure over low bearing capacity soil. It is also easier to explain to the customer and to the public about the idea and effectiveness of such a solution. Excavation provide removal of all weak material under the road out to expose a firm layer of sufficient bearing capacity to accommodate the new structure. Thereafter an embankment of appropriate thickness is constructed on the exposed firm layer to enable the design to be fulfilled with a minimum threat of settlement or shear failure (Munro \& MacCulloch, 2006).

Methods that leave the low bearing capacity soil in place and avoid the disadvantages of bulk earthworks are now becoming increasingly more attractive to engineers as road construction budgets reduce and more cost-effective solutions are sought. Environmental and waste minimization considerations are also added as advantages for methods that build on the weak soil in place. Methods that leave the weak soil in place can be divided in six groups of techniques that utilize the underlying low bearing capacity soil as a load bearing layer. Those groups are:

- strength improvement

- load modification

- reinforcement

- vertical drainage

- piling

- soil stabilisation

In Latvia until 2018, the weak bearing capacity soil exchange method was the main and mostly used for ground stabilization. In 2018 at one of the road building sites during the construction work significant deformations of the road structure occurred. As a result, construction works were stopped, and additional project solutions were developed. 
For the first time in Latvia the combined soil column and pile column construction method had been used (Latvian State Roads, 2018). After the implementation of the project, soil bearing capacity provision has become a hot topic in Latvia.

\section{Evaluation of road geotechnical design methods}

The selection of a proper solution for the construction or improvement design of a road over weak soil will usually be based on rational considerations, such as acceptable budget and other resources, together with the performance requirements expected for the new structure. The most important thing for a road design engineer is to correctly identify the causes, problems, and factors that could affect the road capacity. The factors which engineer has to consider to rationally and safely choose the right method for ground reinforcement by evaluating the pros, cons and limitations of each method is discussed in (Munro, 2004) (see Table 1).

Table 1. Evaluation of road geotechnical design methods

\begin{tabular}{|c|c|c|}
\hline Solution & Advantages & Disadvantages \\
\hline Rerouting & Avoids potential problems with soils. & Requires alignment revision. \\
\hline $\begin{array}{l}\text { Excavation of } \\
\text { weak soil and } \\
\text { replacement }\end{array}$ & $\begin{array}{l}\text { Proven, reliable, well known } \\
\text { technology }\end{array}$ & $\begin{array}{l}\text { Problems with disposal of excavated } \\
\text { material and high quality of fill material. } \\
\text { High water table. Not the cheapest solution }\end{array}$ \\
\hline $\begin{array}{l}\text { Displacement } \\
\text { or partial } \\
\text { excavation }\end{array}$ & $\begin{array}{l}\text { Proven technology. The displaced } \\
\text { weak soil to the sides of the } \\
\text { embankment can enhance the } \\
\text { embankment stability }\end{array}$ & $\begin{array}{l}\text { Not suitable for all soil types. Requires } \\
\text { substantial quantities of fill material for the } \\
\text { buried embankment and longer construction } \\
\text { time for displacement and surcharge affects } \\
\text { to be effective }\end{array}$ \\
\hline $\begin{array}{l}\text { Displacement } \\
\text { assisted by } \\
\text { water jetting }\end{array}$ & $\begin{array}{l}\text { Established intermediate technology. } \\
\text { Does not require weak soil } \\
\text { excavation. Should achieve a good } \\
\text { bearing capacity on the displaced } \\
\text { embankment structure }\end{array}$ & $\begin{array}{l}\text { Same as for displacement or partial } \\
\text { excavation }\end{array}$ \\
\hline $\begin{array}{l}\text { Displacement } \\
\text { by blasting }\end{array}$ & $\begin{array}{l}\text { Used together with displacement } \\
\text { and/or partial excavation solutions. } \\
\text { Established intermediate technology. } \\
\text { Does not require weak soil } \\
\text { excavation. Should achieve a good } \\
\text { bearing capacity on the displaced } \\
\text { embankment construction }\end{array}$ & $\begin{array}{l}\text { Same as for displacement or partial } \\
\text { excavation. Operating with explosives. Can } \\
\text { only be used in open sites with no utilities, } \\
\text { etc. }\end{array}$ \\
\hline
\end{tabular}




\begin{tabular}{lll}
\hline \multicolumn{1}{c}{ Solution } & \multicolumn{1}{c}{ Advantages } & \multicolumn{1}{c}{ Disadvantages } \\
\hline Strength & Minimizes amount of fill material. & Time needed for preloading can extend \\
improvement & Does not require weak soil excavation & construction time. Unpredictable loading \\
through & and disposal & schedule and possibility of required double \\
preloading & & handling. Requires comprehensive site \\
& & investigation and laboratory testing ahead \\
& & of works and onsite monitoring system \\
\hline
\end{tabular}

\begin{tabular}{ll}
\hline $\begin{array}{l}\text { Strength } \\
\text { improvement } \\
\text { by }\end{array}$ & $\begin{array}{l}\text { Improves the bearing capacity of } \\
\text { the underlying weak soil so that } \\
\text { it can support the weight of the }\end{array}$ \\
& $\begin{array}{l}\text { in-service embankment. The time } \\
\text { for consolidation and secondary } \\
\text { compression can be accelerated }\end{array}$ \\
\hline $\begin{array}{l}\text { Strength } \\
\text { improvement }\end{array}$ & $\begin{array}{l}\text { Minimizes secondary compression } \\
\text { sy stage }\end{array}$ \\
constructionent of the new embankment. \\
& $\begin{array}{l}\text { Higher embankments can be } \\
\text { constructed without shear failure in } \\
\text { the underlying weak soil. Does not } \\
\text { require weak soil excavation and } \\
\text { disposal }\end{array}$
\end{tabular}

Load Less fill material required. Reduces

modification loadings on the underlying weak soil by profile and the amount of land required The time needed for surcharging can extend construction time. Requires comprehensive site investigation ahead of works and onsite monitoring system

lowering Increases stability and the depth and

Long construction time needed for the various stages to take effect can extend the embankment construction time. Requires onsite monitoring system

Load Increases stability and the depth and

modification length of the critical slip circle. Low

by pressure grade fill material (even weak soil)

berms can be used as fill mass in berms

Requires a modification of alignment. May not be possible if bridge clearances or other structures are critical. May give problems with bearing capacity of embankment

Requires additional fill material and additional land for the wider construction. Increases the overall weight of the embankment. Consolidation settlements may be increased as a result of the spread of load from the pressure berm

\begin{tabular}{ll}
\hline Load & Increases stability and the depth and \\
modification & length of the critical slip circle \\
by slope & \\
reduction &
\end{tabular}

Requires additional fill material and additional land for the wider construction. Increases the overall weight of embankment. Consolidation settlements may be increased as a result of the spread of load from the wider slopes

\begin{tabular}{ll}
\hline Load & Less bearing capacity necessary on \\
modification & the weak soil foundation. Usually \\
by lightweight & does not need the underlying weak \\
fill & soil to be strengthened. Lighter \\
& embankment construction generally \\
& means less future settlement
\end{tabular}

Price and transport of the specialized lightweight materials. Design and placing of lightweight materials may require special arrangements. Environmental considerations particularly with groundwater. Bearing capacity of the lightweight embankment may be limited 


Solution Advantages Disadvantages

Embankment Limited site disturbance. Provides strengthening reinforcement and stability effect using for the short and medium term.

geotextiles Reduced differential settlements and and geogrids lateral stresses on the weak surface. Minimizes need for embankment fill material. No excavation and disposal

Embankment Limited site disturbance. Provides strengthening and stability reinforcement effect using timber for the short and medium term. raft Reduced differential settlements and lateral stresses on the weak surface. Minimizes need for embankment fill material. No excavation and disposal

Embankment Limited site disturbance. Provides strengthening long term stiff foundation for the using concrete embankment. Reduced differential rafts, settlements and lateral stresses on galvanized the weak surface. Minimizes the need steel sheeting for fill material. No excavation and disposal

\begin{tabular}{ll}
\hline Vertical & Reduced time of primary \\
drainage & consolidation and secondary \\
& compression
\end{tabular}

Piling $\quad \begin{aligned} & \text { No excavation and disposal. Limited } \\ & \text { site disturbance. Minimal or no } \\ & \text { settlement. No additional time } \\ & \text { required for surcharge effects }\end{aligned}$

Mass stabilization method
No excavation and disposal. Reduces settlements and adds to bearing capacity of the weak soil. Smaller demand of fill material compared to other preloading techniques
The overall settlement of the embankment is not reduced. The geotextile/geogrid requires gently operations. Creep may affect the long-term performance of the geotextile. Geogrid requires higher quality fill material

The overall settlement of the embankment is not reduced. Can be damaged by construction equipment during placing of embankment fill. High element of manual labour required for fabrication of the raft. Timber raft must be submerged. Relatively unpredictable period of bio segregation

Overall settlement of the embankment is not reduced. Relatively long curing time for concrete. High element of manual labour required for fabrication of the raft
Acceleration of primary consolidation and secondary compression results in significant settlements during the construction period. Performance of drains affected by buckling, heave, smear

Does not rely on strength of in-situ weak soil. No support assumed from surrounding soil. Usually needs a continuous concrete slab or geotextile load transfer platform. High depths to load bearing stratum.

Expenses

The time needed for preloading can extend the construction time. Unpredictable loading schedule. Requires laboratory testing ahead of works and onsite monitoring system 


\section{Experience of soil reinforcement methods in Latvia}

\subsection{Handbook of ground structure reinforcement and stabilization}

Until 2019 there have been no recommendations, specifications or manuals in Latvia that summarise and describe the methods of soil consolidation, for example, road embankments over pile foundations, vertical drainage soils consolidation, ground piles under the embankment, etc. solutions in cases where road structure is designed over sections with poor bearing capacity. Then the structure cannot provide sufficient support in its natural way to ensure the necessary road surface stability throughout its intended lifetime. Thus, each designer is guided by his own experience, knowledge, prejudices and safety concepts, which creates the risk that irrational and unnecessarily expensive solutions can be developed, or perhaps cheap solutions that do not meet specific needs (Latvian State Roads, 2019).

In 2019, a handbook about road structure on soil with weak bearing capacity reinforcement and stabilization was developed. It summarises and describes soil reinforcement methods - road embankments over pile foundations, vertical drainage soil consolidation, ground piles under the embankment, etc. The handbook gives solutions in cases where road construction is designed in stages with poor bearing capacity so that it does not provide sufficient support in its natural way to ensure the necessary road surface stability throughout its intended lifetime. The handbook helps solve the common issues to deal with in terms of designing the weak soil reinforcements needed in road construction, and it will certainly be a useful support and assistant for road engineers to design subgrade reinforcement solutions and to rationalize the choice of solutions.

The handbook helps use the existing low bearing capacity soil in the most efficient and rational way to design a road. Procedures and methodologies have been developed that describe how to assess subsoil and how to develop specific feasibility studies, including life cycle cost analysis (LCCA), to provide the required bearing capacity and functionality of the subsoil based on expected traffic loads, geological and climatic conditions, properties of existing soils (Latvian State Roads, 2019).

For each project, the technical and economic justification of methods for soil reinforcement and improvement depends on the choice of 
method(s) and its/their functions. In order to evaluate the justification Bearing Capacity of the use of a particular soil improvement and reinforcement method, it is necessary to evaluate the technical characteristics of the road construction, construction stages of the project and technological requirements, the requirements and quality criteria defined in the project, restrictions and non-technical risk assessment results. The geotechnical survey report and road construction parameter data should be evaluated before comparing and evaluating the optimal soil reinforcement and improvement methods for a specific project. In order to assess the need for soil reinforcement and improvement, the following cases and boundary conditions need to be considered:

- the subsoil cannot provide sufficient bearing capacity or the expected irregular and total deformations will exceed safe road operation requirements;

- steep slopes, retaining walls, etc.;

- need to construct a work platform or a bypass;

- need to identify or define operational requirements for the road structure;

- need to identify time, spatial and environmental constraints;

- need to clarify project-specific and site-specific restrictions;

- need to identify restrictions on the use of different soil reinforcement and improvement techniques;

- need to compare different methods of soil consolidation and improvement (Latvian State Roads, 2019).

\subsection{Experience of soil excavation and replacement}

In Latvia until 2018, the weak bearing capacity soil exchange method was the main and mostly used for ground stabilization. Such construction technology is expensive, time- and resource-consuming.

Examples of the implemented objects:

- $\quad$ P128 $24.48 \mathrm{~km}$ to $\mathbf{3 2 . 0 2} \mathbf{~ k m}$ (Sloka-Talsi) section of motorway, reconstructed in 2017. The road was last constructed during this period in the 1970s and the reconstruction was long delayed because the road surface for almost the entire length of the road was muddy. During construction $63000 \mathbf{~ m}^{3}$ of peat was excavated and replaced with a suitable soil.

- A12 $114.34 \mathrm{~km}$ to $125.14 \mathrm{~km}$ (Rēzekne-Ludza) section of motorway, commissioned in 2018. The construction works were complicated by the massive replacement of peat with a loadbearing soil at the base of the road - 300 meters long at a depth of six meters. 
- P5 20.54 km to 25.00 km (Tīnūži-Ogre) section of motorway, commissioned in 2018. During the road construction a complete reconstruction of the road pavement structure was carried out soil exchange, construction of new frost resistant road pavement

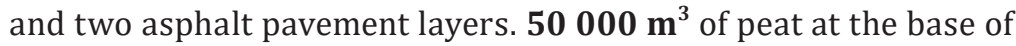
road construction was replaced with sand.

- P62 $44.15 \mathrm{~km}$ to $\mathbf{5 7 . 5 4} \mathrm{km}$ (Bašķi-Preilì) section of motorway, commissioned in 2018. To stabilize the road foundations, the soil had to be exchanged to a depth of nine meters and was heavily burdened by heavy rain. Due to rains, the soil in the construction areas was dampened; therefore, the passage was difficult, and the traffic disrupted. $120 \mathbf{0 0 0} \mathbf{~ m}^{3}$ of soil was exchanged within the site.

\subsection{Pile columns}

In 2018 season, the two sections of the national regional motorway Augšlīgatne-Skrīveri (P32) $(47.20 \mathrm{~km}$ to $60.29 \mathrm{~km}$ and $61.27 \mathrm{~km}$ to $71.27 \mathrm{~km}$ ) had the largest road repairs within the national road network. During the reconstruction of the road from $49.50 \mathrm{~km}$ to $50.00 \mathrm{~km}$ weak bearing capacity soil - a bog section with a peat layer at a depth of $10 \mathrm{~m}-$ was determined. This was revealed by additional research carried out by JSC "Celuprojekts". The possible solutions for soil stabilization were also examined (Latvian State Roads, 2018).

During the road reconstruction project, the geotechnical research was conducted to a depth of four meters. The geological boreholes did not show weak bearing capacity soils, so it was assumed that weak bearing capacity had already been replaced. However, it turned out that there was an overgrown lake beneath the embankment soils. The

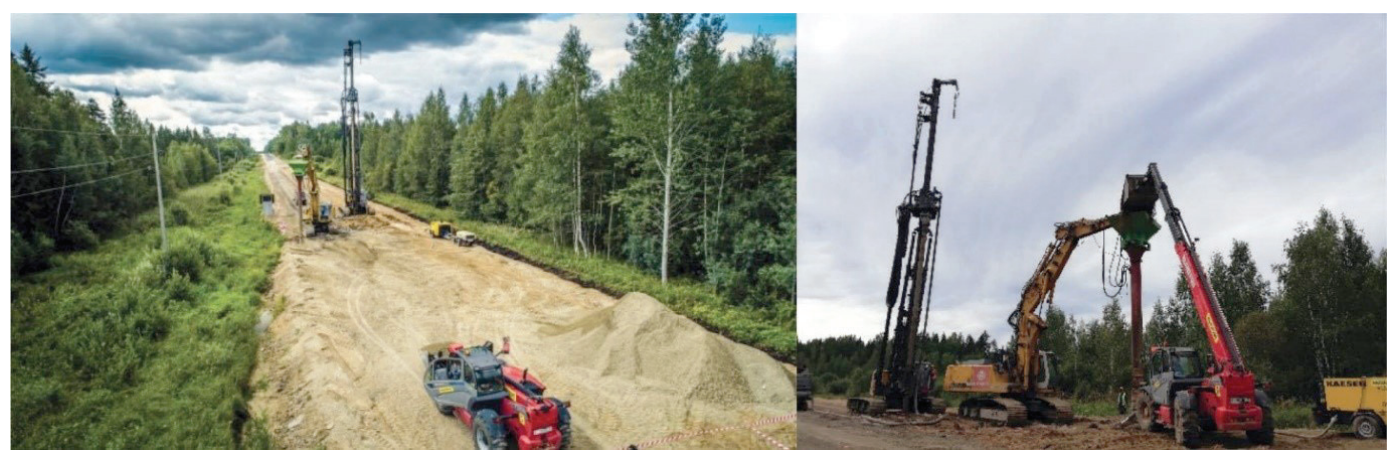

Figure 2. Construction of combined columns and pile columns 
suspicion arose during the construction work and was confirmed by Bearing Capacity geological investigation. It was found that there were both peat and sludge under a thick layer of gravel. As a result, at more intense traffic and at higher loads, the road could be deformed, and the investment made would not be sustainable.

There were two options for solving the problem of the weak loadbearing soil:

- excavation of weak bearing capacity of soil up to a depth of $10 \mathrm{~m}$ in a sufficiently wide roadway area, including existing communications. It was not only expensive, but there was also the risk to disturb the soil layers near the road. In addition, soil replacement takes time, so it can settle and stabilize, which means that it would not be possible to continue the construction works and finish during the season. Using this method would cost almost one million euros (excluding VAT);

- applying new technology that had not been practiced on the national road network before and strengthening the ground with piles. Similar technology was used for bridges and building foundations, but roads had not had such an experience in Latvia. The cost of this method would be almost 600 thousand euros (excluding VAT), and with the construction of piles and combined columns, it would be possible to proceed immediately with the pavement without delaying the construction of the entire road section.

In order to stabilize this soil, a method of constructing combined columns and pile columns had been used for the first time in the national road network. $30 \mathrm{~cm}$ wide and up to $6 \mathrm{~m}$ long concrete columns were built, and above them $60 \mathrm{~cm}$ wide up to $2 \mathrm{~m}$ long gravel/crushed columns. A total of 952 columns were constructed, arranged in a $2.5 \mathrm{~m} \times$ $2.0 \mathrm{~m}$ grid. A team of specialists from Poland came to Latvia to engage in the constructions works (Latvian State Roads, 2018).

\subsection{Crushed stone stabilization berm construction}

In 2019, the consequences of the road deformations on Peldu Street were eliminated and technical solutions for conservation were developed. Peldu Street is used as the main access point to Sigulda bobsleigh arena. The condition of the road structure was assessed as critical. Slippage of the road structure due to the Gauja water, groundwater and other factors made it dangerous to allow vehicles to drive along Peldu Street.

During the pavement structure monitoring, it was found that the deformations progressed over time and the crack width increased. 
In order to prevent a complete collapse of the road structure and to restore the movement of the transport it was necessary to prevent the development of deformations.

Several slope and road reinforcement options were developed for conservation technical solutions. One of the main factors of the project was the limited time to complete the construction works and to restore the traffic on Peldu Street. Due to the limited construction time, the main solution was to construct mineral berm and wrap road construction layers in high-strength geotextiles.

\subsection{Gabion wall construction}

On the A2 motorway between Riga and Sigulda in 2019 in the area above the Rauna River, the longitudinal profile of the road was raised, the embankment slopes reinforced with gabion support walls. Gabion support walls were designed for road section $92.34 \mathrm{~km}$ to $92.40 \mathrm{~km}$. The existing embankment was constructed of moraine loam (geological survey has a bond $\mathrm{Cu}=20 \mathrm{kPa}$ ), so there would be a high risk of slope slipping and soil crushing if the vertical load was increased by the additional embankment. The problem was solved with the help of soil anchors, which served to keep the old embankment body from slipping and falling. Gabions were intended to be built on crushed stone. Ground anchors were selected for the load of $350 \mathrm{kN}$; tensile force $120 \mathrm{kN}$ (U-profile divider beam would be installed in the middle of the gabion to equalize the force). Tensioning was performed after the embankment was created and compacted to the full height of the tensioned gabion. The front of the gabion facade $(\sim 50 \mathrm{~cm}$ thick) was built after tensioning

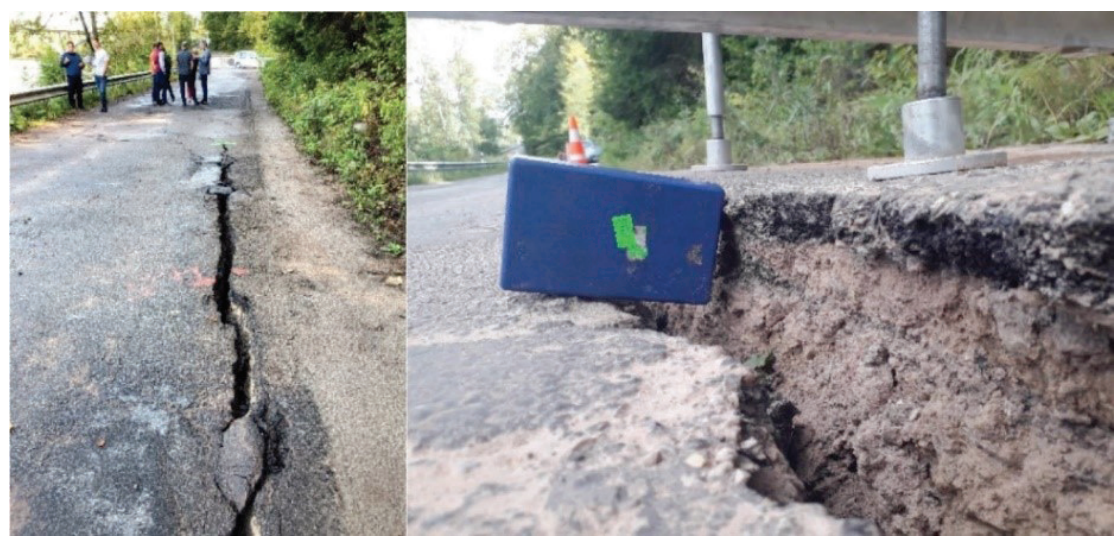

Figure 3. Deformations on existing roads 
the anchors. Behind the walls of the gabions a vertical drainage system Bearing Capacity was built for draining the surface of the carriageway.

\subsection{Consequences of wrong decisions made in road design}

The road pavement design shall ensure that the materials used are designed to carry the intended load-bearing capacity by constructing the structural layers in accordance with the minimum requirements

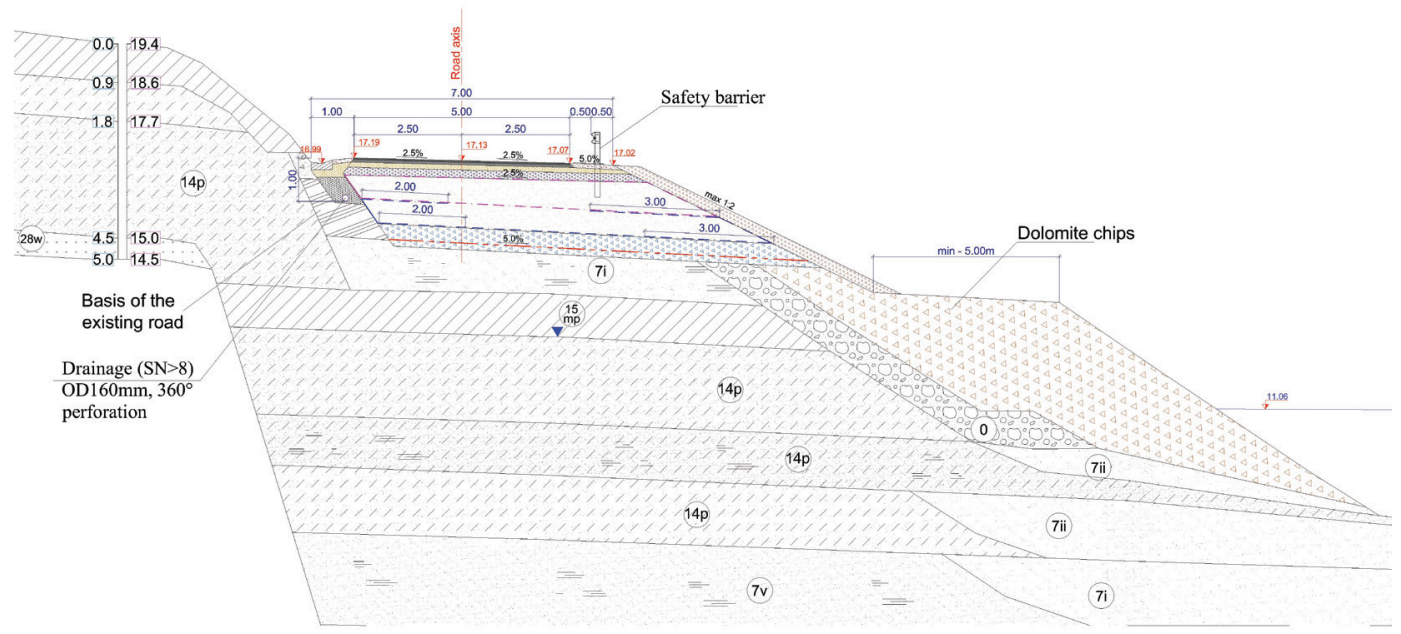

Figure 4. Project solution

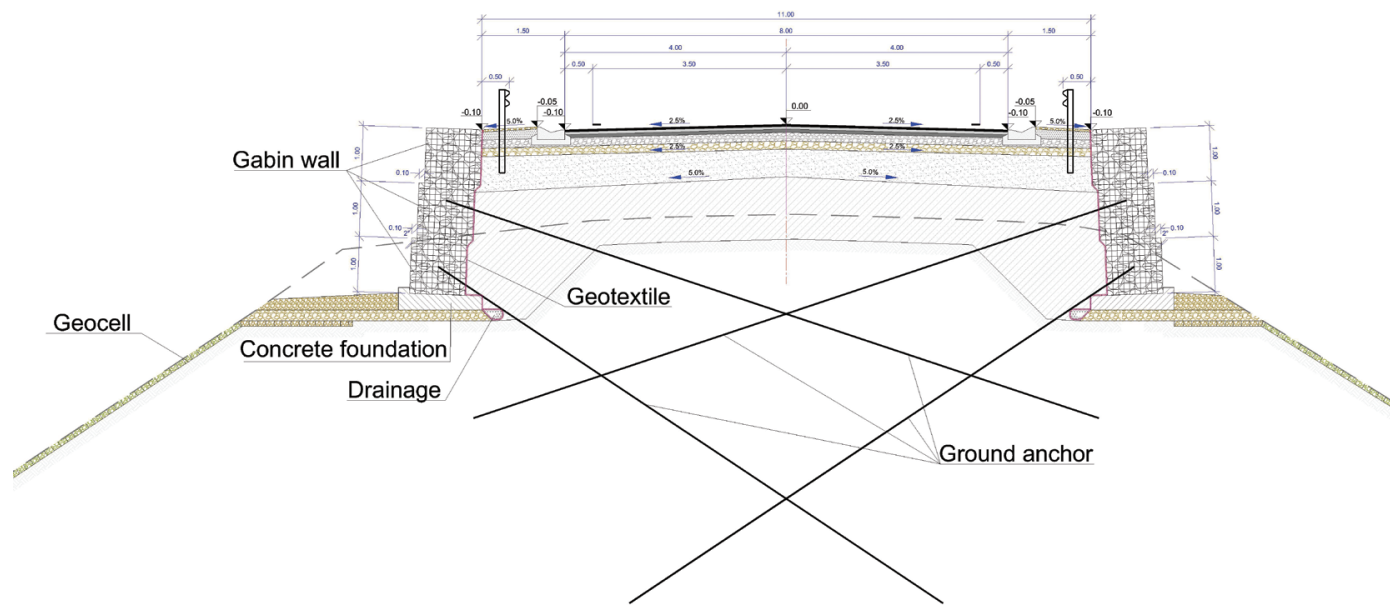

Figure 5. Project solution for national motorway A2 
specified in "Road Specifications". Each construction project is different due to pavement and ground solutions, technical specifications, different geotechnical, topographic and other conditions.

The road engineer considering all available data is responsible for making the right project decisions. However, in projects often a situation arises when, due to lack of experience or knowledge, the road engineer makes mistakes and chooses an inappropriate road design solution that fails to provide the required quality requirements. An example is the construction work started on the A2 motorway between Riga and Sigulda in 2019. Although the road construction is not over and a new layer of asphalt will be laid in the spring, on some sections of the road have appeared cracks. The road builder points out that the cracks are not caused by the pavement construction, but by the adjacent swamp. It has been found that there is also a layer of peat under the pavement structure and it has not been removed. Only the top of the road has been reconstructed. Old asphalt has been mixed with other components and a cement-related recycled mixture has been made. The road designer considered that the peat layers under existing road structure were sufficiently compacted. Now it is clear that additional geotechnical research will be needed and possibly it will be necessary to make some changes in project solutions. Geotechnical drilling and testing are expected in the spring. Only then it will be possible to understand why these cracks are occurring and to choose the right methods to ensure the longevity of the road structure.

\section{Conclusions}

Ground conditions for engineering works can never be totally certain and invariably constitute a significant risk for projects. Some uncertainty will always remain even after the most rigorous design procedures. For a road engineer during project development the analysis of the existing geological situation is one of the most important things to perform. Improperly or mistakenly determining the properties of existing soils can affect the performance of the road structure.

Road designers worldwide are facing poor load-bearing soils. It is a challenge for an engineer to find a way how to ensure road load-bearing capacity and prevent the occurrence of various deformations. Various methods and technologies for ground structure reinforcement and stabilization have been developed worldwide. Each of the developed technologies for weak and unstable soil reinforcement, stabilization is designed to solve a specific problem. Inaccurately and carelessly identifying the causes of problems, road deformations can affect the 
performance of the recently designed road and even make the existing Bearing Capacity problem worse. It is very important to identify the main and most significant risks that can affect the road construction and to choose the most rational reinforcement method.

In Latvia until 2018 the only one ground reinforcement option for road design over peat were used. The national road industry lacks experience and knowledge using other methods. In 2018 season within the national road network P32 during the reconstruction of the road from $49.50 \mathrm{~km}$ to $50.00 \mathrm{~km}$ weak bearing capacity soil - a bog section with a peat layer at a depth of $10 \mathrm{~m}$ - was discovered. In order to stabilize this soil, a method of constructing combined columns and pile columns had been used for the first time in the national road network. $30 \mathrm{~cm}$ wide and up to $6 \mathrm{~m}$ long concrete columns were built, and above them $60 \mathrm{~cm}$ wide up to $2 \mathrm{~m}$ long gravel/crushed columns. Saving of 400000 euros was achieved in this project. After implementation of this project, a group of road engineers started to work on the handbook of ground structure reinforcement and stabilization. It was released in 2019. Engineers in Latvia still have a lot to learn about ground structure reinforcement and stabilization on low bearing capacity soils, but it has been a considerable progress for the past two years. Our knowledge and experience over the years will grow.

\section{REFERENCES}

Guyer, J. P. (2018). An Introduction to Road Design for Cold Regions (2nd ed.). California, El Macero: The Clubhouse Press.

Kalnina, L. (2019). Bogs in Latvia. National Encyclopaedia. Retrieved from https://enciklopedija.lv/skirklis/27677-purvi-Latvijā (in Latvian)

Latvian State Roads. (2019). Developing Solutions for Soil Bearing Capacity of Road Pavement, Handbook. (in Latvian)

Latvian State Roads. (22 August 2018). Cela pamatu stabilizēšanai pie Madlienas tiek izbūvētas 952 pālu un kombinētās kolonnas; būvdarbus veic speciālisti no Polijas [Article about road stabilization using combined piles under road construction]. Retrieved from https://lvceli.lv/uncategorized/cela-pamatustabilizesanai-pie-madlienas-tiek-izbuvetas-952-palu-un-kombinetas-kolonnas-buvdarbus-veic-specialisti-no-polijas/ (in Latvian)

Munro, R., \& MacCulloch, F. (2006). Managing Peat Related Problems on Low Volume Roads. Executive Summary. Roadex III.

Munro, R. (2004). Dealing With Bearing Capacity Problems on Low Volume Roads Constructed on Peat. Including Case Histories From Roads Projects Within ROADEX Partner Districts. Roadex II.

Stinkulis, G. (2019). Geological Structure of Latvia. National Encyclopaedia. Retrieved from https://enciklopedija.lv/skirklis/26128-Latvijas-ǵeoloǵiskāuzbūve 